\title{
PROTECTION OF CONSUMER RIGHTS IN PACKAGE TRAVEL, PACKAGE HOLIDAYS AND PACKAGE TOURS IN SLOVAKIA
}

\author{
Jarmila Wefersová 78
}

https://doi.org/10.31410/itema.2018.193

\begin{abstract}
Tourism is one of the areas of the economy that is rapidly developing and there are significant changes in this sector as well. In addition to traditional distribution chains, Internet is becoming an increasingly important medium through which travel services are offered or sold. Travel services are combinations in the form of traditional predefined packages of services and the use of modern IT technologies (online retailer). The Slovak legislation is based on the provisions of Article 169. section 1 and Article 169 section $2 a$ of the Treaty on the Functioning of the European Union (TFEU), which provides that the Union must contribute to the achievement of an elevated level of consumer protection through measures adopted pursuant to Article 114 TFE. To ensure legal certainty, the legislation stipulates the obligation on operators to carry out the activities of a travel agency solely based on a business license for travel. In addition, the law tightens the travel agency's information obligations to passengers. The aim of this scientific article is to point out and declare in detail the responsibility of entrepreneurs in selling their products. In the context of business relationship there are two subjects, on the one hand the individual traveler as a consumer, and on the other side the provider of services (a legal person), who must take full responsibility for the services provided.
\end{abstract}

Keywords: Protection of consumer rights, Tourism, Online tourism, Travel agency.

\section{INTRODUCTION}

T The aim of this scientific study is to clarify the issue of tourism, online tourism, consumer and consumer protection with the help of selected relevant sources and to approximate Act 170 of 15 May 2018 on Tours, Associated Tourism Services, Certain Business Conditions in Tourism and amendments of some laws. The National Council has passed the above-mentioned law and the law enters into force from 1.1.2019, in the following mentioned as Act 170/2018 Z.z. [1] Tourism is a major economic sector with a very favorable impact on economic growth and employment not only in individual countries, but also across Europe and the world. The importance of tourism for economy, society and individuals became known to the countries involved in the second half of the 20th century. States have created legal, economic and other prerequisites to promote tourism business. The development of tourism as result of technological development has its own specifics.

Online tourism, e-tourism, web tourism are all understood today in tourism science as having a web-based technology requested by a consumer or self-booked tourist primary services. In this context, touristic primary services are defined as all services provided by (tourist) service providers that are needed to generate and design a journey (e.g. transport and accommodation). As secondary tourist services above all are understood additional services (e.g. travel insurance, entrance tickets, etc.). Online tourism has become increasingly important in both the private and business sectors in recent years. The importance of online tourism is growing worldwide.

\footnotetext{
${ }^{78}$ Faculty of Management, Comenius University Bratislava, Odbojárov 10, SK 82005 Bratislava 25, Slovakia
} 
For this purpose, we present the table Global Online Travel Market Overview 2016 and Digital Travel Sales Worldwide from 2014 to 2020. The Internet opens new distribution channels for service providers and tour operators. The offer for and in tourism on the Internet has been developing positively for 20 years. The special interest lies in the search for flights and train connections, information on international holiday regions and hotels or last minute offers. The number of on-line bookings is also increasing and above all the sale of airline and train tickets.

E-commerce brings benefits for many involved. For subjects involved in tourism it is no longer a question of joining the Internet, but the way in which to do so. There is a significant redistribution of tasks on the electronic tourism market. While there has been a clearly visible end-user orientation over the past years, in recent years there is a stronger concentration on travel agents using mainly Central Reservation Systems (CRS). The basis of the product of the central reservation system is booking and selling accommodation via the Internet continuously 24 hours a day 7 days a week. The centers of CRS operators are stepping up efforts to use the Internet as another and may be better distribution channel.

Central reservation systems undermine the by antitrust authorities forced neutrality and reduce market transparency if they, for example, offer airlines a customer one-to-one marketing. Oneto-One-Marketing makes it possible to address the consumer individually in the form of business-to-consumer or business-to-business. Other interesting and forward-looking online ecommerce solutions include specialized Internet platforms/channels and virtual travel agencies, creating various communities of travelers. One of the most important features is to find the most suitable offers for a client. For the sake of clarity and transparency in the interpretation of the law, this study deals with the concepts of tourism, online tourism, consumer and consumer protection as well as with the Act 170 of 15 May 2018 on Tours, Associated Tourism Services, Certain Business Conditions in Tourism and amendments of some laws.

\section{OBJECTIVE AND METHODOLOGY}

The aim is to get closer to the Protection of consumer rights in package travel, package holidays and package tours in Slovakia. To reach the target, we worked with relevant information about tourism, consumer and consumer protection. We gained data from books or articles, as well as from electronic publications and Internet articles. In addition, we looked at the Consumer protection in Slovakia based on the European Directive and analyzed the new law 170 on tours and related tourism services and some conditions of making business in tourism. Consumer protection in the new conditions of online tourism requires this new legal framework. By analyzing and synthesizing, we examine the conditions for protecting consumers in tourism services.

Related to the issue are several terms. For the sake of clarifying the content and preventing mistakes in interpretation, the basic concepts how consumer rights must be protected are set out in the law. The creator of the law is the Ministry of Economy of the Slovak Republic. The National Authority urges everyone involved to use the unified terminology.

\section{TOURISM AS AN ECONOMIC PHENOMENON}

Tourism contributes significantly to the economic and social development of countries in Europe and the world in relation to cultural and natural heritage, the traditions and culture of Europe and individual countries. The development of tourism because of technological 
development has its own specifics. Tourism has been and is studied under macroeconomic and microeconomic aspects.

In the first half of the 20th century, tourism has been investigated as an economic activity by A. Mariotti, A.J. Norval and M. Trois. In this period, Swiss W. Hunziker and K. Krapf were the most successful in the study of economic aspects of tourism. These authors define "tourism as a set of relationships and phenomena arising from travel and residence of persons in a foreign place, unless the purpose of the stay is permanent or long-term or short-term gainful employment". [2]

The UNWTO Code defines "tourism as an activity which, most often, relates to rest and relaxation, sport and access to culture and nature, should be planned and implemented as a privileged means of individual and collective fulfillment; when exercised with a sufficiently open mind, is an irreplaceable factor in self-education, mutual tolerance and learning about the legitimate differences between people and cultures and their diversity." [3]

M. Gúčik, who defined tourism as an industry with a cross-sectional character, was also studying quantification of economic benefits in tourism. The lack of relevant tourism data in terms of traffic and its performance has led to the need to create a specific collection of this data. The assessment of economic and social benefits of tourism required the introduction of a tourism satellite account. This Satellite Tourism Account was developed by the World Tourism Organization (UNWTO) in collaboration with the UN Statistical Commission and the OECD.

Tourism also acts as a multiplier of economic activities. The question of the final effect and the destination function of tourism both from the point of view of the individual traveler and from the point of view of the organizers of tourism as producers of goods and services satisfying demand in tourism, is addressed by several authors, among others the above-mentioned M. Gúčik. [4]

The European Union has an important role to play in creating the same rules for the development of cooperation between Member States in different sectors, but in particular by emphasizing the good functioning of markets for the benefit of consumers and thus protecting them.

In the tourism industry, online tourism has become increasingly important in recent years, both in the private and business sectors. The terms online tourism, e-tourism, web tourism, platform tourism vary from text to text. In general, it nowadays refers to all primary tourist services requested or self-booked by an end user via a web-based technology. In this context, touristic primary services are defined as all services provided by (tourist) service providers that are needed to generate and design a journey (e.g. transport and accommodation).

As secondary tourist services, above all additional services (e.g. travel insurance, entrance tickets, etc.) are understood. The number of bookings, which are actually handled only by technical systems without the intervention of an editor, is unknown.

\section{ONLINE TOURISM - E-TOURISM - WEBTOURISM - PLATFORM TOURISM}

Gone are the days where reservations and booking of travel were only possible by visiting travel agencies or ordering by phone. Nowadays travel websites and mobile apps have been making digital travel arrangements increasingly easy. For current day travellers, it is almost unthinkable 
not to be able to independently plan and book travel arrangements beforehand. Many internet users appreciate the ability to create their own itineraries with the help of digital tools such as travel planning websites, price comparison websites or review portals, which frequently provide visitors with the option to directly book accommodation at listed locations.

"E-tourism is understood as all digitized and web-based transactions used by the tourism industry to optimize value-added processes, thereby increasing competitiveness." [5] The importance of online tourism is growing worldwide more and more. The following tables are featured on Global Online Travel Market Overview 2016.

Table 1: Global Online Travel Market Overview 2016[6]

\begin{tabular}{|l|c|}
\hline Digital travel sales worldwide & $564,87 \mathrm{bn}$ USD \\
\hline Growth of digital travel sales worldwide & $15,4 \%$ \\
\hline Growth of hotel online sales values worldwide & $10,3 \%$ \\
\hline Growth of air travel online sales values worldwide & $6,8 \%$ \\
\hline
\end{tabular}

Table 2: Digital Travel Sales Worldwide from 2014 to 2020 (in Billion U.S. Dollars) [7]

\begin{tabular}{|c|c|}
\hline 2014 & 470.97 \\
\hline 2015 & 496.21 \\
\hline 2016 & 564.87 \\
\hline 2017 & 629.81 \\
\hline 2018 & 693.91 \\
\hline 2019 & 755.94 \\
\hline 2020 & 817.54 \\
\hline
\end{tabular}

This timeline shows the online travel sales worldwide from 2014 to 2020. In 2016, global online travel sales totaled 564.87 billion U.S. dollars. This figure is projected to grow to 755.94 billion U.S. dollars in 2019.

The Internet opens new distribution channels for tourism service providers and tour operators. The individual traveler, i.e. consumer, is very interested in searching for flights and train connections, information on international holiday regions and hotels or last-minute offers. The number of on-line reservations is also increasing, and most of the airline and train tickets are sold in this way.

The benefits of E-commerce are well known and evident. For subjects involved in tourism, it is no longer a question of joining the Internet, but the way in which to do so. There is an interesting redistribution of tasks in the electronic tourism market. While there has been a clearly visible end-user orientation over the past years, at present, it is mainly in the central reservation systems (CRS) that there is a stronger concentration on travel agents.

\section{CONSUMER PROTECTION FOR TRAVEL AND RELATED TOURISM SERVICES}

The concept of consumer has several definitions. We may not confuse the concept of consumer with the terms customer, payer or household. Even in European law, the definition of the concept of consumer is not uniform but this person is always adapted for the purpose of a specific adjustment. A costumer who purchases and uses services for his own needs is the ultimate consumer, the purpose of which is of a non-professional nature. Market expansion together with financial and technological innovation creates new challenges for consumer protection. The EU has responded to these challenges by strengthening the consumer policy 
and creating an independent consumer protection competence at EU level.EU legal acts provide protection to consumers before and during holidays in cases where a travel agency declares bankruptcy, if the holiday does not correspond to the offer in the catalog or, for example, at raising the price for the holiday or when changing the recreation center without the consent of the customer.

Legislative acts of the EU include European Parliament and Council Directive (EU) 2015/2302 on packages of travel and related travel services, Regulations of the European Parliament and of the Council No. 524/2013 on consumer dispute resolutions online, Directive 2011/83/EU of the European Parliament and of the Council on consumer rights Regulation (EU) No. 181/2011 on rights in bus and coach transport, Regulation (EU) No 1177/2010 of the European Parliament and of the Council on the rights of passengers in maritime and inland waterway transport.

In secondary law there are more regulations for the protection and obligations of passengers, such as Regulation (EC) No. 261/2004 of the European Parliament and of the Council establishing common rules on compensation and assistance to passengers in the event of denied boarding, in the event of cancellation or long delay of flights, (EC) No 1107/2006 on the rights of disabled persons and persons with reduced mobility in the air transport sector, Regulation (EC) 1371/2007 on the rights and obligations of rail passengers, Regulation (EC) No. 392/2009 on the liability of carriers of passengers by sea in the event of accidents.

The obligations of the Slovak Republic vis-à-vis the European Union relate to the transposition period of Directive (EU) 2015/2302, as of 1 January 2018. The degree of compatibility of the draft law with that of the European Union is complete. The Ministry of Economy and the Ministry of Transport and Construction of the Slovak Republic are the co-operating ministries. The basis of consumer rights protection in Slovakia was Act No. 634/1992 ZB. on consumer protection.

Consumer law is currently undergoing major changes due to the expansion of the market and technological innovations. In Slovakia, it is supposed to secure since 1.1. 2018 Act 170/2018 Z.z. about tours, related tourism services, some conditions of tourism business, and amendments to certain laws, a high level of passenger protection for the purchase of tours and combined travel services, to remove ambiguities and gaps in the current legislation. It takes over with the relevant European directive.

The above law in Slovakia provides the good functioning of the markets for the benefit of consumers and therefore their protection. The subject matter of this law is:

- rights and obligations relating to the provision of tourism services on basis of a travel contract or the provision of associated tourism services,

- the scope and power of public authorities in the field of tourism,

- certain conditions of business in tourism,

- liability and sanctions for breach of the obligations laid down by this Act.

This law does not apply to tours or related tourism services like the following:

- provided for less than 24 hours if there is no accommodation,

- provided on an occasional basis, to a limited group of travelers and without the aim of making a profit,

- purchased under a framework contract for the provision of traveler services in connection with business trips, - concluded between a trader and person, who at 
the conclusion and the fulfillment of the contract acts in the context of his business or profession or a person acting on his or its behalf.

The Civil Code and a special regulation govern the areas to which this Act applies.

The most relevant definition is the definition of the consumer by the Slovak Act No. 250/2007 Z.z. The definition of the consumer is adapted according to $\S 2$ and of the Consumer Protection Act and says: "A consumer is a natural person who does not act in the course of his business, employment or occupation when he concludes and performs a consumer contract."Act 170/2018 Z.z. defines the following terms: tourism services, traveler, trader, bankruptcy protection, bankruptcy protection provider, sales place, durable carrier, unavoidable and extraordinary circumstances, commencement of the journey, repatriation return of the passenger to his place of departure, journey/tour, travel provider, travel agency. We will approach some of the terms of this law. It's good to take a closer look at some of them.

Tourism services in law $170 \S 2$ include transportation and accommodation which is not a natural part of the transport and is not intended for the purpose of housing, rental of motor vehicles and other tourism services that are not a natural part of the tourism service. The law defines a traveler as a natural person who concludes a travel contract or a contract establishing a combined tourism service and a trader as a person who, when concluding and fulfilling a contract of travel or contracts constituting a related tourism service, is acting within the scope of his business, through another person acting on his or her behalf, which may be a travel provider agency, a travel selling agency or a tourism service provider.

The new law protects the consumer in the event of bankruptcy, hence guarantees the fulfillment to the extent of this law under an insurance contract or a bank guarantee agreement concluded between the travel agency and the provider of bankruptcy protection. A place of sale is an establishment or other place where a trader normally carries on his business, including a web site or other means of remote communication, which allow the conclusion of a contract without the simultaneous physical presence of the parties. A durable medium is a means of retaining the information addressed to the passenger or merchant, such as paper, e-mail, USB key, CD, DVD, memory card, or hard disk of the computer.

Travel is defined in law $170 \S 3$ as a combination of at least two different types of tourism services purchased for the same purpose, regardless of whether separate contracts with individual tourism service providers are concluded in the case of tourism services. They may be purchased at a single point of sale, offered and sold for a total price, or purchased from different traders via interconnected online reservation systems, where a trader with whom a first travel service contract is concluded sends the name and surname, payment details and the electronic address of the traveler to another trader or other traders and with this trader or traders a tourism service contract shall be concluded not later than 24 hours after the reservation of the first tourist service has been confirmed.

Related Services in Tourism pursuant to Section 4 are a combination of at least two different types of tourism services purchased for the same purpose, which do not provide a tour, with separate tourism contracts being concluded with a number of tourism service providers. 


\section{TRAVEL PROVIDER AGENCIES, TRAVEL SELLING AGENCIES}

A travel provider agent under Section 5 of the Law 170 is a trader combining tourism services for the purposes of touring, selling or offering for sale tours and concluding a travel contract or arranging related tourism services.

A travel selling agent is a trader who, in the scope of business, creates a combination of tourism services that are not a tour, offers and sells to another travel agent or travel agency for resale. The obligation of a travel provider agency and travel selling agency as defined in Sections 7 and 8 is to designate a point of sale and materials promoting tours or related tourism services and other materials relating to the sale of tours or associated travel services for the traveler, including their electronic features, including their electronic form by the words "travel agency", if this name does not contain a business name.

It is important to protect the consumer in the event of bankruptcy under $\S 9$. The passenger who paid the travel agency for travel services that are part of the tour or associated tourism services has the right to immediate payment under the protection in case of bankruptcy if the travel agency due to its bankruptcy or if it fails to arrange for services to be repatriated, or it will not return to the passenger the prepayment or the cost of the tour if the tour has not been completed or has only partially taken place. The travel agency is required to agree with the contractor for the bankruptcy protection of at least $30 \%$ of the annual planned revenue from sales of tours and related tourism services when concluding a contract for insolvency protection. To protect against bankruptcy in the form of insurance, the Civil Code and the Special Insurance Act are covering adequately. The travel provider agency or travel selling agency that sells a tour is required to provide the passenger with the appropriate form before entering into a travel contract or before sending an offer whose admission may result in the conclusion of a travel contract.

Subject of the Act 170/2018 Z.z. is the travel contract itself, the assignment of a travel contract, the change of the price of the tour and other conditions of the tour, the cancellation of the tour contract before the start of the tour. A traveler is entitled to withdraw from the tour in unavoidable and extraordinary circumstances shortly before the tour. A standard information form prior to the conclusion of the tour contract is standard rights if the travel agency which arranges the online connected tourism service pursuant to $\S 4$ of Act no. 170/2018 Z.z. is at the same time a carrier selling a return ticket.

If, after the booking of one tourist service and the payment for it, the traveler books through this travel agency additional travel services related to this trip or holiday, not the same rights are applied, which apply to tours under Act no. 170/2018 Z. z . The travel agency can withdraw from the tour contract without the obligation to compensate the passenger for the number of participants who are less than the minimum number of participants required under the tour contract.

The Ministry of Economy of the Slovak Republic (hereinafter "the Ministry of Economy") fulfills the tasks of a contact point of the Slovak Republic within the network of contact points of the Member States of the European Union. The supervisory authority - The Ministry of the Interior of the Slovak Republic maintains and publishes at its web site the current list of travel agencies. 


\section{CONCLUSION}

The main objective of the contribution is to define and analyze the consumer, its protection, online tourism and legislation in this area within the EU and Slovakia. Research objects are the institutes, phenomena and processes related to online tourism, consumer protection and the relevant legislation. There are several concepts that we have approached in this article post. All entities operating in the tourism sector will use this terminology uniformly. The importance of tourism for the economy, society and the individual became known to most of the countries all over the world in the second half of the 20th century. States have created legislative, economic and other prerequisites to support tourism business in means to support the development of tourism supply and demand.

In recent decades, online tourism has grown. The Internet opens new distribution channels for service providers and tour operators. People are very interested in seeking flights and train connections, information on international holiday regions and hotels or last minute offers. The proportion of online reservations is also growing significantly, and above all the sale of flight and train tickets.

The issue is very current, so we have decided to explore the area of consumer protection and related concepts. The good functioning of the markets for the benefit of the consumer and therefore its protection are ensured in Slovakia by Law 170/2018 Z.z. on tours and related tourism services, some conditions of tourism business and will enter into force on 1.1.2019.This law is intended to ensure a high level of protection for travelers in the purchase of tours and related travel services, to remove ambiguities and gaps in the current legislation. The Ministry of Economics within the context of tourisms industry seeks to protect travelers and people who are interested in travelling.

The law has also introduced new basic concepts, apart from defining narrower the term" tour/trip/journey" it will positively and negatively define the new concept of "associated/related tourism services". At present, it is common for passengers to buy a ticket over the Internet and to order in addition an accommodation or car from a rental facility. According to the new law, every person or company providing multiple such services at the same time will be considered as a travel agency and will have to adapt the business accordingly.

The insurance of travel agencies for tours has been increased to $30 \%$. By law, any entity interested in offering tourism services meeting the definitive criteria for tours or related travel services will be required to carry out these activities only as a travel agent and solely on the basis of a trade license. At the same time, every travel agent will have the obligation to have a secure protection in case of insolvency in the form of insurance or a bank guarantee in a sufficient amount.

The law also clearly defines the various options for changes to the travel contract before the start of the tour. At the same time, the travel agents' duty to provide information is strengthened. Law 170/2018 Z.Z responds to the challenges of tourism because of technological development. At the same time, it takes over the EU's legislative acts. EU law introduces a number of regulations in the field of consumer protection. These regulations aim to unify the rights of citizens towards traders throughout the European Union. 


\section{REFERENCES}

[1] Zákon 170/2018 170 o zájazdoch, spojených službách cestovného ruchu, niektorých podmienkach podnikania $\mathrm{v}$ cestovnom ruchu a o zmene a doplnení niektorých zákonov. [Online], [Retrieved $\quad$ September $\quad 12, \quad$ 2018], https://www.nrsr.sk/web/Default.aspx?sid=zakony/zakon\&MasterID=6707

[2] Hunziker, W., Krapf, K. (1942) Grundriss der allgemeinen Fremdenverkehrslehre, Polygrafischer Verlag, pp. 243 -391.

[3] UNWTO, Globálny etický kódex cestovného ruchu, [Online], [Retrieved April 22, 2018], http://ethics.unwto.org/sites/all/files/docpdf/slovakia_0.pdf, pp.5

[4] Gúčik, M., (2011) Cestovný ruch. Politika a ekonómia, Knižnica cestovného ruchu 20, DALI-BB, s.r.o. Banská Bystrica, pp. 188, ISBN 978-80-89090-80-8

[5] $E$ - Tourism [Online], [Retrieved August 2, 2018] http://www.webtourismus.de/tips/tourismus-definitionen.aspx

[6] Global Online Travel Market Overview (2016) [Online], [Retrieved September 15, 2018], https://www.statista.com/topics/2704/online-travel-market/

[7] Digital Travel Sales Worldwide from 2014 to 2020 [Online], [Retrieved September 2018]https://www.statista.com/statistics/499694/forecast-of-online-travel-salesworldwide/Zákon 170/2018 170 o zájazdoch, spojených službách cestovného ruchu, niektorých podmienkach podnikania $\mathrm{v}$ cestovnom ruchu a o zmene a doplnení niektorých zákonov. 